\title{
Evaluation of Heavy Metal Pollution on Soil in Vaderbijlpark, South Africa
}

\author{
F. M. Mtunzi ${ }^{1, ~}$, E. D. Dikio ${ }^{1}$, S. J. Moja ${ }^{2}$ \\ ${ }^{1}$ Department of Chemistry, Vaal University of Technology, Vanderbijlpark, South Africa \\ ${ }^{2}$ Department of Environmental Sciences, Florida Campus, University of South Africa, Florida, South Africa
}

Email address:

fanyana@vut.ac.za (F. M. Mtunzi), ezekield@vut.ac.za (F. M. Mtunzi)

\section{To cite this article:}

F. M. Mtunzi, E. D. Dikio, S. J. Moja. Evaluation of Heavy Metal Pollution on Soil in Vaderbijlpark, South Africa. International Journal of Environmental Monitoring and Analysis. Vol. 3, No. 2, 2015, pp. 44-49. doi: 10.11648/j.ijema.20150302.13

\begin{abstract}
In this study, inductive coupled plasma-optical emission spectroscopy (ICP-OES) is employed for the evaluation of soil pollution for selected metals in the Vanderbijlpark area of South Africa. Soil samples investigated were collected from five different sites in the city based on their proximity to the industrial areas of Vanderbijlpark. Soil samples were collected from close to traffic robots, farms, township schools, Iemas garage and central East 5 (CE5) suburbs. The results obtained show metal levels at the robot decrease in the order $\mathrm{Pb}>\mathrm{Zn}>\mathrm{V}>\mathrm{Bi}>\mathrm{Ni}>\mathrm{Li}>\mathrm{As}>\mathrm{Sn}>\mathrm{Co}>\mathrm{Cu}>\mathrm{Mo}>\mathrm{Sb}>\mathrm{Hg}>\mathrm{Se}$; at the farm they decrease in the order $\mathrm{Pb}>\mathrm{Zn}>\mathrm{Bi}>\mathrm{Li}>\mathrm{Sn}>\mathrm{As}>\mathrm{V}>\mathrm{Cu}>\mathrm{Mo}>\mathrm{Sb}>\mathrm{Ni}>\mathrm{Co}>\mathrm{Cd}>\mathrm{Se}>\mathrm{Hg}$; in the township school they decrease in the order $\mathrm{Pb}>\mathrm{Zn}>\mathrm{Cu}>\mathrm{Li}>\mathrm{V}>\mathrm{Sn}>\mathrm{As}>\mathrm{Ni}>\mathrm{Bi}>\mathrm{Mo}>\mathrm{Sb}>\mathrm{Co}>\mathrm{Cd}>\mathrm{Se}>\mathrm{Hg}$; at the Iemas garage the decreasing order is $\mathrm{Pb}>\mathrm{Zn}>\mathrm{V}>\mathrm{Li}>\mathrm{Sn}>\mathrm{As}>\mathrm{Bi}>\mathrm{Cu}>\mathrm{Ni}>\mathrm{Mo}>\mathrm{Co}>\mathrm{Cd}>\mathrm{Se}>\mathrm{Hg}>\mathrm{Sb}$ and in the CE5 suburb the decreasing order is $\mathrm{Pb}>\mathrm{Zn}>\mathrm{V}>\mathrm{Li}>\mathrm{As}>\mathrm{Cu}>\mathrm{Sn}>\mathrm{Ni}>\mathrm{Mo}>\mathrm{Co}>\mathrm{Bi}>\mathrm{Cd}>\mathrm{Sb}>\mathrm{Se}>\mathrm{Hg}$. $\mathrm{In}$ all the sample points, the levels of lead $(\mathrm{Pb})$ was found to be high, particularly at the farm and the township school area. However, the concentrations of all other metals at all the sampling points were within the US-EPA maximum allowable limits.
\end{abstract}

Keywords: Inductive Coupled Plasma, Optical Emission Spectroscopy, Soil, Heavy Metals

\section{Introduction}

Soil contamination by heavy metals is a major concern because at high concentration they can harm human life and the environment [1]. Some of the contributors to soil contamination include mining, steel and iron industry, smelting procedures, chemical industries, traffic, agriculture and domestic activities [2]. Once heavy metals are deposited in the soil, they are not degraded and persist in the environment for a long time and cause serious environmental pollution [3-5]. They accumulate in soils and plants and would have a negative influence on physiological activities of plants such as photosynthesis, gaseous exchange and nutrient absorption which result in plant growth reduction and dry matter accumulation [6-7]. There is a growing concern about the possibility of soil contamination resulting in uptake by plants and the introduction of elements in vital food chains affecting food safety [8]. Animals that graze on such contaminated plants and drink from polluted waters, as well as marine lives that breed in heavy metal polluted waters also accumulate these metals in their tissues and milk if lactating [9]. In small concentrations, traces of heavy metals in plants or animals are not toxic except that cadmium, lead and mercury are toxic even at low concentrations [10-11].

Metals exist in a number of different soluble and particulate forms which influence their mobility and bioavailability [12-13]. Since their toxicity is related to their existing species, their speciation is increasingly attracting more attention [14]. To monitor soil contamination by heavy metals, the Environmental Protection Agency of the United States (USEPA) [8, 15], recommends that concentrated nitric acid be used as an extractant for the determination of total contents in soils even though the results do not often represent a good indication of bioavailability to plants [16]. Open beakers heated on hot plates, digestion tubes in a block digester and digestion bombs placed in microwave ovens are the most commonly used equipment to digest solid sample matrices [17]. Digestion of solid samples for elemental analysis is an established routine sample preparation method with the usage of nitric acid in a closed system under elevated temperatures and pressure and it has been used since 1860 [18]. The increasing improvement for element 
determination in an extract, together with the evidence that exchangeable metals correlate better with plant uptake, has led to the development of single extraction methods which use less aggressive solutions [19-20]. Microwave-assisted sample digestion technique has been used since 1980s and is adopted by the EPA under EPA Methods 3051 and 3051a for extraction of metals from sludge, soil or sediments [18]. This method provides rapid, safe, and efficient digestion and is not prone to losses of volatile metals [21].

In the present study, five soil samples were treated by microwave assisted digestion and the resulting solutions were analysed by Inductive coupled plasma-optical emission spectroscopy (ICP-OES). This is due to the fact that ICPOES has low detection limits, large dynamic range and high precision [18]. The objective of the present study is to provide information regarding accumulation of heavy metals in the soil of heavily industrialized Vanderbijlpark area of South Africa. Furthermore, information about heavy metal content in this area is scarce.

\section{Experimental}

\subsection{Study Area}

Vanderbijlpark $\left(26^{\circ} 70 \mathrm{~S}, 27^{\circ} 85 \mathrm{E}\right)$ is a classic example of an industrial township of the $20^{\text {th }}$ century. It falls under Sedibeng municipality and is an industrial city next to the Vaal River in Southern Gauteng, South Africa. The economy of Sedibeng District Municipality has for the largest part of its existence been dominated by heavy manufacturing and still is the dominant feature of regional economy. There are two main subsector of manufacturing divided into fabricated metal and chemicals. In the metal sector, the Arcelor-Mittal (formerly ISCOR) steel plant, the Cape Gate Davsteel wire and steel plant and the ferromanganese plant of Samancor, are the three main large baseline plants in the District, while DCD-Dorbyl Heavy Engineering is the biggest manufacturer of massive engineered products in Southern Africa. SASOL, of which the primary plant in the District is based in the Metsimaholo Local Municipality in the Free State, is the major player in the chemical industry sector in the District [22].

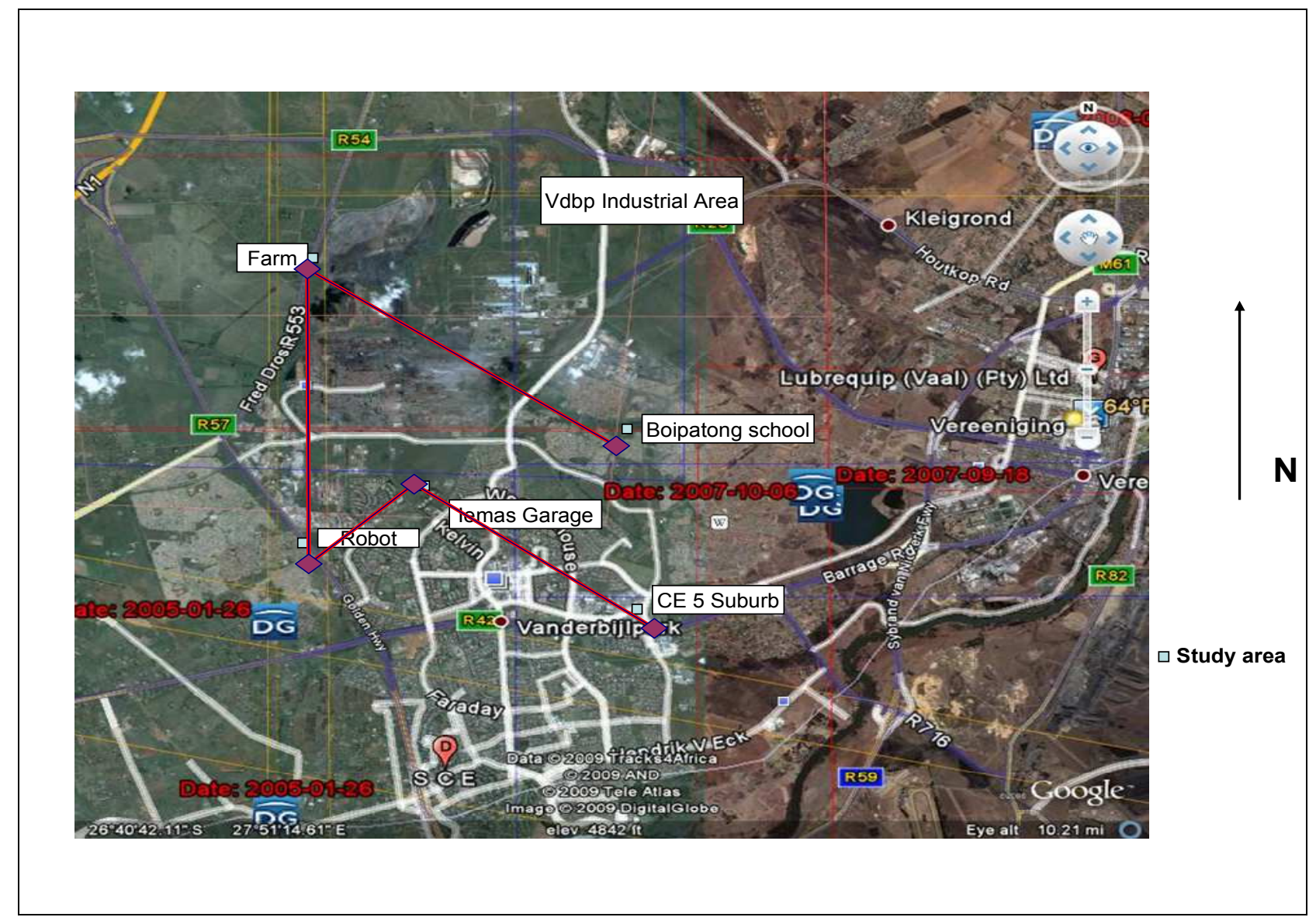

Figure 1. Map showing study areas in Vanderbijlpark.

\subsection{Sampling}

The soils investigated in this experiment were sampled from Vanderbijlpark area of South Africa, which is known to be highly industrialized as shown on the map in Figure 1. At each sampling point, about $2 \mathrm{~kg}$ of soil at surface level (0-10 $\mathrm{cm}$ in depth) were collected. Three samples were collected in each point, thoroughly mixed in a clean container made of perfluoroalkoxy polymer (PFA) to obtain a representative sample. Collected soils were crushed and passed through a 2 $\mathrm{mm}$ sieve before stored in a labeled polythene bags prior to analysis. 


\subsection{Sample Preparation and Heavy Metal Determination}

Samples were dried at $105^{\circ} \mathrm{C}$ for 3 hours. About $0.2 \mathrm{~g}$ of sample was accurately weighed into a container made of PFA which was then placed in a microwave pressure vessel. Sample preparations were done according to the method described by Moore et al. [23] without minor improvements. The digested samples were analysed for metals using an iCAP 6000Perkin Elmer Inductively Coupled Plasma-Optical Emission Spectrometer (ICP-OES) from Thermo Electron Corporation (Cheshire, United Kingdom). Pump rate $=45$ rpm, Nebuliser argon pressure $=0.3$ L. $\min -1$, Centre tube $=$ $2 \mathrm{~mm}, \mathrm{RF}$ forward power $=1150 \mathrm{~W}$, Coolant gas flow $=12$ L.min-1, Auxiliary gas flow $=0.5$ L.min-1 and Integration time $=15$ sec. European soil certified reference material (EURO876-1 from Industrial Analytical in S.A.) was used to prepare a $1.000 \mathrm{~g} / \mathrm{L}$ stock solution from which a series of standard solutions were prepared under the same experimental conditions as the samples to validate the method. Acceptable linear calibration graphs were produced and detection limits of the elements were determined from the averages of three repeat ( 3 times) analyses. In order to test the accuracy of the method, one gram of each soil sample was diluted with one gram of $\mathrm{As}, \mathrm{Bi}, \mathrm{Cd}, \mathrm{Co}, \mathrm{Cu}, \mathrm{Hg}, \mathrm{Li}, \mathrm{Mo}$, $\mathrm{Ni}, \mathrm{Pb}, \mathrm{Sb}, \mathrm{Se}, \mathrm{Sn}, \mathrm{V}$ and $\mathrm{Zn}$ salts in separate beakers and digested. Glassware was soaked for $24 \mathrm{~h}$ in dilute $(5 \% \mathrm{v} / \mathrm{v})$ nitric acid, rinsed with distilled water and dried in an oven before use. A Consorte C862 bentchtop conductivity/pH/DO meter with separate beakers was used to determine soil $\mathrm{pH}$ using soil-water ratio of $1: 5$

\subsection{Data Analysis}

Data obtained were analysed using Analyse-it ${ }^{\circledR}$ v.22, which is the statistical software for Microsoft Excel. Results are presented as \pm standard deviation. Statistical variations were considered significant at $\mathrm{p}<0.05$.

\section{Results and Discussion}

Limit of detection (LOD) and limit of quantification (LOQ) were calculated by using equations 1 and 2 respectively.

$$
\begin{aligned}
\mathrm{LOD} & =\frac{3 \times \mathrm{SD}_{\text {blank }} \times \text { Conc. } \text { sample }}{\mathrm{I}_{\text {sample }}-\mathrm{I}_{\text {blank }}} \\
\mathrm{LOQ} & =\frac{3 \times \mathrm{SD}_{\text {blank }} \times \text { Conc.sample }}{\mathrm{I}_{\text {sample }}-\mathrm{I}_{\text {blank }}} \times 10
\end{aligned}
$$

Where $\mathrm{SD}_{\text {blank }}$ is the standard deviation for the signal recorded on the blank for the element studied

Quality control study for the metals studied using the microwave assisted digestion method was obtained as percentage recoveries and are presented in Table 1. The percentage recoveries of these elements ranged from $43.5 \%$ to $112.3 \%$ with mercury being the lowest and nickel being

\begin{tabular}{|c|c|c|c|c|c|}
\hline \multirow{2}{*}{$\begin{array}{l}\text { Element } \\
(\mathrm{mg} / \mathrm{L})\end{array}$} & \multicolumn{5}{|c|}{ European soil certified reference material (EURO 876-1) } \\
\hline & $\begin{array}{l}\text { Limit of detection (LOD) } \\
\text { (ppm) }\end{array}$ & $\begin{array}{l}\text { Limit of quantification } \\
\text { (LOQ) (ppm) }\end{array}$ & Experimental value (SD) & Theoretical value (SD) & Average \% recovery \\
\hline As & $<0.00869$ & 0.0674 & $0.13(0.12)$ & $0.16(0.03)$ & 92.8 \\
\hline $\mathrm{Bi}$ & $<0.0093$ & 0.0918 & $0.009(0.01)$ & $0.011(0.005)$ & 54.3 \\
\hline $\mathrm{Cd}$ & $<0.0002$ & 0.0018 & $0.88(0.09)$ & $0.89(0.1)$ & 95.9 \\
\hline Co & $<0.0017$ & 0.0137 & $9.96(0.7)$ & $9.98(1.3)$ & 100.76 \\
\hline $\mathrm{Cu}$ & $<0.0017$ & 0.0225 & $0.425(0.04)$ & $0.420(0.2)$ & 99.28 \\
\hline $\mathrm{Hg}$ & $<0.0022$ & 0.024 & $0.006(0.001)$ & $0.007(0.001)$ & 43.5 \\
\hline $\mathrm{Li}$ & $<0.0013$ & 0.0108 & $0.09(0.01)$ & $0.10(0.04)$ & 98.9 \\
\hline Mo & $<0.0011$ & 0.008 & $0.002(0.003)$ & $0.002(0.001)$ & 88.9 \\
\hline $\mathrm{Ni}$ & $<0.0012$ & 0.0106 & $2.44(0.06)$ & $2.46(0.2)$ & 112.3 \\
\hline $\mathrm{Pb}$ & $<0.0032$ & 0.0355 & $8.8(0.14)$ & $8.7(1.6)$ & 100.2 \\
\hline $\mathrm{Sb}$ & $<0.0046$ & 0.0387 & $0.003(0.001)$ & $0.0027(0.002)$ & 97.9 \\
\hline $\mathrm{Se}$ & $<0.0088$ & 0.0758 & $0.0001(0.02)$ & $0.0003(0.0001)$ & 89.4 \\
\hline Sn & $<0.0133$ & 0.0968 & $0.67(0.1)$ & $0.67(0.01)$ & 90.8 \\
\hline V & $<0.0011$ & 0.0116 & $0.11(0.05)$ & $0.12(0.6)$ & 99.8 \\
\hline $\mathrm{Zn}$ & $<0.0031$ & 0.0232 & $20.0(0.04)$ & $20.9(4.8)$ & 105.9 \\
\hline
\end{tabular}
the highest.

Table 1. The Limit of detection, Limit of quantification and average \% recoveries of different elements.

The results of the $\mathrm{pH}$ values and the total mean metal concentrations from five sampling points are presented in
Table 2 while the correlation of the metals is given in Table 4. 
Table 2. Metals results of soil from 5 selected areas.

\begin{tabular}{|c|c|c|c|c|c|}
\hline & Robot (mg/kg) & Farm (mg/kg) & Township school (mg/kg) & Iemas garage (mg/kg) & CE-5 (mg/kg) \\
\hline & $\mathrm{n}=3, \mathrm{pH}=7.8$ & $\mathrm{n}=3, \mathrm{pH}=6.9$ & $\mathrm{n}=3, \mathrm{pH}=6.8$ & $\mathrm{n}=3, \mathrm{pH}=7.4$ & $\mathrm{n}=3, \mathrm{pH}=7.1$ \\
\hline As & $0.0555(0.002)$ & $0.085(0.009)$ & $0.0658(0.007)$ & $0.0664(0.007)$ & $0.060(0.02)$ \\
\hline $\mathrm{Bi}$ & $0.0896(0.005)$ & $0.169(0.06)$ & $0.0536(0.01)$ & $0.0578(0.005)$ & $0.0075(0.004)$ \\
\hline $\mathrm{Cd}$ & $0.0103(0.001)$ & $0.0085(0.0001)$ & $0.0085(0.001)$ & $0.0159(0.009)$ & $0.0072(0.003)$ \\
\hline Co & $0.0340(0.003)$ & $0.0112(0.006)$ & $0.0255(0.008)$ & $0.0188(0.004)$ & $0.0184(0.009)$ \\
\hline $\mathrm{Cu}$ & $0.104(0.02)$ & $0.0631(0.009)$ & $0.172(0.005)$ & $0.0559(0.005)$ & $0.0557(0.01)$ \\
\hline $\mathrm{Hg}$ & ND & ND & ND & ND & ND \\
\hline $\mathrm{Li}$ & $0.0683(0.004)$ & $0.151(0.007)$ & $0.142(0.06)$ & $0.0924(0.01)$ & $0.0724(0.02)$ \\
\hline Mo & $0.0174(0.06)$ & $0.0479(0.008)$ & $0.0414(0.009)$ & $0.0263(0.004)$ & $0.0243(0.008)$ \\
\hline $\mathrm{Ni}$ & $0.0751(0.005)$ & $0.0366(0.004)$ & $0.056(0.001)$ & $0.0428(0.002)$ & $0.0417(0.008)$ \\
\hline $\mathrm{Pb}$ & $1.15(0.09)$ & $5.261(1.36)$ & $2.922(0.11)$ & $2.577(0.8)$ & $2.388(0.09)$ \\
\hline $\mathrm{Sb}$ & $0.0079(0.0008)$ & $0.0374(0.007)$ & $0.0371(0.009)$ & ND) & ND \\
\hline $\mathrm{Se}$ & ND & ND & ND & $\mathrm{ND}$ & ND \\
\hline $\mathrm{Sn}$ & $0.0466(0.007)$ & $0.0865(0.008)$ & $0.0890(0.009)$ & $0.0796(0.008)$ & $0.0538(0.02)$ \\
\hline V & $0.0905(0.005)$ & $0.0659(0.004)$ & $0.104(0.008)$ & $0.132(0.01)$ & $0.0774(0.07)$ \\
\hline $\mathrm{Zn}$ & $0.246(0.09)$ & $0.268(0.09)$ & $0.2784(0.07)$ & $0.245(0.09)$ & $0.195(0.05)$ \\
\hline
\end{tabular}

\section{$\mathrm{ND}=$ Not detected}

In general, Table 2 shows that the metal levels at the robot decrease in the order $\mathrm{Pb}>\mathrm{Zn}>\mathrm{V}>\mathrm{Bi}>\mathrm{Ni}>\mathrm{Li}>\mathrm{As}>\mathrm{Sn}>$ $\mathrm{Co}>\mathrm{Cu}>\mathrm{Mo}>\mathrm{Sb}>\mathrm{Hg}>\mathrm{Se}$; at the farm they decrease in the order $\mathrm{Pb}>\mathrm{Zn}>\mathrm{Bi}>\mathrm{Li}>\mathrm{Sn}>\mathrm{As}>\mathrm{V}>\mathrm{Cu}>\mathrm{Mo}>\mathrm{Sb}>$ $\mathrm{Ni}>\mathrm{Co}>\mathrm{Cd}>\mathrm{Se}>\mathrm{Hg}$; in the township school they decrease in the order $\mathrm{Pb}>\mathrm{Zn}>\mathrm{Cu}>\mathrm{Li}>\mathrm{V}>\mathrm{Sn}>\mathrm{As}>$ $\mathrm{Ni}>\mathrm{Bi}>\mathrm{Mo}>\mathrm{Sb}>\mathrm{Co}>\mathrm{Cd}>\mathrm{Se}>\mathrm{Hg}$; at the Iemas garage the decreasing order is $\mathrm{Pb}>\mathrm{Zn}>\mathrm{V}>\mathrm{Li}>\mathrm{Sn}>\mathrm{As}>\mathrm{Bi}>$ $\mathrm{Cu}>\mathrm{Ni}>\mathrm{Mo}>\mathrm{Co}>\mathrm{Cd}>\mathrm{Se}>\mathrm{Hg}>\mathrm{Sb}$ and in the CE5 suburb the decreasing order is $\mathrm{Pb}>\mathrm{Zn}>\mathrm{V}>\mathrm{Li}>\mathrm{As}>\mathrm{Cu}>$ $\mathrm{Sn}>\mathrm{Ni}>\mathrm{Mo}>\mathrm{Co}>\mathrm{Bi}>\mathrm{Cd}>\mathrm{Sb}>\mathrm{Se}>\mathrm{Hg}$. The difference in the trend may be attributed to the fact that environmental dependent parameters are never static due to changes in temperature, $\mathrm{pH}$ and nature of human perturbation on the natural ecosystem [24]. The concentration of lead $(\mathrm{Pb})$ was found to be high in all the sampling points compared to other studied metals. Its concentration was found to be 5.261 (1.36) ppm on the farm and lowest at the robot at $1.15(0.09) \mathrm{mg} / \mathrm{kg}$ (Figure 1 and Table 3). The farm is not used for farming but as dumping site by a steel producing company in the area. The high levels of mercury might be due to these dumping activities. What is also noticeable from these results is that, soils with high $\mathrm{pH}$ values show high concentration of metals as can be noticed with the farm and the nearby school soils as shown in Table 2. Qishlaqi et al., 2007 in their studies observed that soil samples with alkaline $\mathrm{pH}$ and high organic matter content accumulate significant high concentrations of heavy metals compared with other soil samples [25]. However, metal such as lead have low solubility at $\mathrm{pH}$ range of 5.5-7.5 [24]. This might mean that the concentrations of lead obtained in this study might not be the true reflection of the actual concentration in the soil sample studied since the $\mathrm{pH}$ 's of the soil samples were in the range 5.5-7.5 and above. The concentrations might be higher. All metals studied are below the minimum allowed concentrations in the soil from different countries and USEPA as can been seen in Table 3 . Anthropogenic sources of $\mathrm{Cu}, \mathrm{Zn}$ and $\mathrm{V}$ include coal burning in residential areas for cooking and space heating as well as burning during industrial alloy and smelting processes [26]. High levels of $\mathrm{V}$ can harm lungs, throat and eyes or cause death whilst Ni can affect the urinary tract, especially the kidneys and may lead to paralysis if not managed [27]. Lead has no known biological role [28]. Lead poisoning can cause learning disability, sterility and growth inhibition [29]. Sources of $\mathrm{Pb}$ includes paint in old houses, metal scrap yards and soil contaminated by leaded petrol since $\mathrm{Pb}$ is not biodegradable and stays long in the environment [30]. The presence of lead on the school grounds is of concern because learners play with the soil and some eat it. Continuous monitoring of metals, particularly those that are toxic in the soil is important since they can affect the health of people and animals if they enter the food chain.

Table 3. Value of Maximum Allowable limits for heavy metals in soil ( $\mathrm{mg} / \mathrm{kg}$ ) from different countries [6].

\begin{tabular}{|c|c|c|c|c|c|c|c|}
\hline Chemical element & Australia & Canada & Poland & Japan & Great Britain & Germany & US-EPA \\
\hline $\mathrm{Cd}$ & 5 & 8 & 3 & - & 3 & 2 & 85 \\
\hline Co & 50 & 25 & 50 & 50 & - & - & $0.3-200$ \\
\hline $\mathrm{Cr}$ & 100 & 75 & 100 & - & 50 & 200 & \\
\hline $\mathrm{Cu}$ & 100 & 100 & 100 & 125 & 100 & 50 & 4300 \\
\hline $\mathrm{Ni}$ & 100 & 100 & 100 & 100 & 50 & 100 & 75 \\
\hline $\mathrm{Pb}$ & 100 & 200 & 100 & 400 & 100 & 500 & 450 \\
\hline $\mathrm{Zn}$ & 300 & 400 & 300 & 250 & 300 & 300 & 7500 \\
\hline As & & & & & & & 75 \\
\hline
\end{tabular}


Table 4. Correlation between metals.

\begin{tabular}{|c|c|c|c|c|c|c|c|}
\hline & As & $\mathbf{B i}$ & Cd & Co & $\mathrm{Cu}$ & $\mathrm{Hg}$ & $\mathbf{L i}$ \\
\hline As & 1 & 0.16 & 0.747 & -0.9 & -0.193 & 0 & 0.774 \\
\hline $\mathrm{Bi}$ & 0.16 & 1 & -0.12 & -0.313 & -0.098 & 0 & 0.475 \\
\hline $\mathrm{Cd}$ & -0.0553 & -0.0208 & 1 & -0.362 & -0.268 & 0 & -0.361 \\
\hline $\mathrm{Co}$ & -0.898 & -0.299 & -0.362 & 1 & 0.564 & 0 & 0.591 \\
\hline $\mathrm{Cu}$ & -0.1934 & -0.0983 & -0.289 & 0.564 & 1 & 0 & 0.301 \\
\hline $\mathrm{Hg}$ & 0 & 0 & 0 & 0 & 0 & 0 & 0 \\
\hline Mo & 0.799 & 0.524 & 0.317 & -0.652 & 0.213 & 0 & 0.995 \\
\hline $\mathrm{Ni}$ & -0.915 & -0.0909 & -0.726 & 0.973 & 0.558 & 0 & -0.511 \\
\hline $\mathrm{Pb}$ & 0.829 & 0.96 & 0.385 & -0.854 & -0.192 & 0 & 0.867 \\
\hline $\mathrm{Sb}$ & 0.422 & 0.686 & -0.0635 & -0.229 & 0.556 & 0 & 0.897 \\
\hline $\mathrm{Se}$ & 0 & 0 & 0 & 0 & 0 & 0 & 0 \\
\hline $\mathrm{Sn}$ & 0.794 & 0.743 & 0.665 & -0.552 & 0.259 & 0 & 0.856 \\
\hline V & -0.0579 & -0.308 & 0.575 & 0.26 & 0.156 & 0 & -0.292 \\
\hline
\end{tabular}

Table 4. (Continue)

\begin{tabular}{|c|c|c|c|c|c|c|c|c|}
\hline & Mo & $\mathrm{Ni}$ & $\mathbf{P b}$ & Sb & Se & Sn & $\mathbf{V}$ & Zn \\
\hline As & 0.799 & -0.915 & 0.829 & 0.611 & 0 & 0.794 & -0.058 & 0.178 \\
\hline $\mathrm{Bi}$ & 0.524 & -0.0909 & 0.657 & 0.484 & 0 & 0.369 & -0.398 & 0.627 \\
\hline $\mathrm{Cd}$ & -0.351 & -0.0037 & -0.221 & 0.395 & 0 & 0.157 & 0.844 & 0.124 \\
\hline $\mathrm{Co}$ & -0.652 & 0.973 & -0.667 & -0.408 & 0 & -0.552 & 0.26 & 0.039 \\
\hline $\mathrm{Cu}$ & 0.212 & 0.558 & -0.192 & 0.235 & 0 & 0.259 & 0.156 & 0.598 \\
\hline $\mathrm{Li}$ & 0.995 & -0.511 & 0.867 & 0.698 & 0 & 0.856 & -0.292 & 0.624 \\
\hline Mo & 1 & -0.562 & 0.911 & 0.691 & 0 & 0.844 & -0.333 & 0.594 \\
\hline $\mathrm{Ni}$ & -0.562 & 1 & -0.738 & -0.349 & 0 & -0.519 & 0.134 & 0.165 \\
\hline $\mathrm{Pb}$ & 0.911 & -0.738 & 1 & 0.616 & 0 & 0.731 & -0.415 & 0.41 \\
\hline $\mathrm{Sb}$ & 0.877 & -0.349 & 0.616 & 1 & 0 & 0.945 & 0.375 & 0.815 \\
\hline $\mathrm{Se}$ & 0 & 0 & 0 & 0 & 0 & 0 & 0 & 0 \\
\hline V & -0.333 & 0.133 & -0.415 & 0.374 & 0 & 0.221 & 1 & 0.156 \\
\hline $\mathrm{Zn}$ & 0.594 & 0.165 & 0.411 & 0.815 & 0 & 0.713 & 0.156 & 1 \\
\hline
\end{tabular}

The correlations between metals were evaluated to establish possible common sources. Positive correlations were established between Mo and $\mathrm{Li}(\mathrm{r}=0.995) ; \mathrm{Pb}$ and $\mathrm{Mo}$ $(\mathrm{r}=0.911)$; $\mathrm{Ni}$ and $\mathrm{Co}(\mathrm{r}=0.973) ; \mathrm{Li}$ and $\mathrm{Pb}(\mathrm{r}=0.867) ; \mathrm{Sb}$ and $\mathrm{Sn}(\mathrm{r}=0.945) ; \mathrm{Zn}$ and $\mathrm{Sb}(\mathrm{r}=815) ; \mathrm{V}$ and $\mathrm{Cd}(\mathrm{r}=0.844)$; $\mathrm{Bi}$ and $\mathrm{Pb}(\mathrm{r}=0.96)$; As and $\mathrm{Pb}(\mathrm{r}=8.29)$ which suggests similar sources. However, some elements have positive correlation but their correlations were poor and suggested different sources (Table 4). Local anthropogenic sources linked to these elemental distributions include steel and metallurgical alloy making processes, road transport, industrial chemical reactions, coal and oil burning activities and windblown dust ${ }^{26}$.

\section{Conclusion}

Monitoring of elements in the soil provides an efficient way to assess their qualitative and quantitative concentrations at distinct locations. The distribution of different metal concentrations in the soils of the selected areas indicated that these areas have been affected by the anthropogenic activities and some are from the same source as shown by the correlations of some metals. Furthermore, the experimental results indicate that the concentrations of the studied metals decrease with the distance far from the industrial area. Of all metals studied, lead $(\mathrm{Pb})$ was found to be high but less than US-EPA allowable limits, particularly on the farm and the township school. This is of concern since lead has been reported to be harmful to humans and also affect the intelligence of children. As a result, more intensive sampling is necessary to monitor any change or increase of the studied metals in the investigated areas over time.

\section{Acknowledgements}

The research was supported by CRC and Department of Chemistry at Vaal University of Technology and the ICPOES was provided by Acelor Mital in Vanderbijlpark South Africa. 


\section{References}

[1] E. M. Fagbote and E. O Olanipekun, American-Eurasian Journal of Scientific Research. 5 (4), 241 (2010).

[2] A. Ene, A. Boşneagă and L. Georgescu, Roman Journal Physics 55 (7-8), 815 (2010).

[3] P. K. Bora, S. Chetry, D. K. Sharma and P. M. Saika, Journal of Chemistry, DOI: 10.1155/609203, 1-7 (2013).

[4] M. A. Ali, M. M. Rahman and M. N. Amin, Journal of Civil Engineering, the Institute of Engineers, Bangladesh 25 (1), 82 (1997).

[5] O. T. Oyelola and A. I. Baatunde, International Journal of Pure and Applied Sciences 2(1): 17 (2008).

[6] E. O. Fagbote and E. O. Olanipekun, American-Eurasian Journal of Scientific Research 5 (4), 241 (2010).

[7] I. Suciu, C. Cosma, M. Todica, S. D. Bolboaca and L. Jantschi, Journal of Molecular Sciences 9, 434 (2008).

[8] K. G. Pujar, S.C. Hiremath, A. S. Pujar, U. S. Pujeri and M. S. Yadawe, Karnataka 2 (1), 76 (2012).

[9] M. I. Yahaya, G. C. Ezeh, Y. F. Musa and S. Y. Mohammad, African Journal of Pure and Applied Chemistry 4 (3), 22 (2010).

[10] W. De Vries, P. F. A. M. Romkens and G. Schutze, Reviews of Environmental Contamination and Toxicology 191, 91(2007).

[11] H. Galas-Gorcher, Food add. Cont. 8, 798 (1991).

[12] L. Yi, Y. Hong, D. Wang and Y. Zhu, Geochemical Journal 41, 235 (2007).

[13] Y. Ge, D. Macdonald, S. Sauvoé and W. Hendershot, Environ. Model. Softw. 20, 353 (2005).

[14] M. Nassef, R. Hannigan, K. A. El Sayed and M. S. Tahawy, Determination of some heavy metals in the environment of Sadat Industrial City. Proceedings of the $2^{\text {nd }}$ Environmental Physics Conference, 18-22 February (2006).

[15] US Environmental Protection Agency Standards for the Use or Disposal of Sewage Sludge, Federal Rigister, 58, 210 (1993).

[16] H. M. Kingston and L. B. Jassie, Safety Guidelines for Microwave Systems on the Analytical Laboratory, in H. M. Kingston and L. B. Jassie, Introduction to Microwave and Decomposition, Theory and Practice, Washington, ACS (1998).

[17] C. Voica, A. Dehelean, A. Iordache and I. Geana, Romanian Reports in Physics 64 (1), 221 (2012).

[18] R. Shirdam, Z. Modarres-Tehrani and F. Dastgoshadeh, Rasayan Journal of Chemistry 1 (4), 920 (2008).

[19] Z. Hussain and M. Islam, Journal of Scientific Research 40 (2), 47 (2010).

[20] V. Ettler, M. Mihaljevič, O. Šebek and T. Grygar, Anal. Chim. Acta 602, 131(2007).

[21] A. D. Hewitt and C. W. Reynolds, Atomic Spectroscopy 11, 187 (1990).

[22] http:// www.vaaltriangle.co.za. Visited 20 January (2013).

[23] C. Moor, T. Lymberopoulou and V. J. Dietrich, Mikrochimica Acta 136, 123 (2001).

[24] J. O. Oti Wilberforce, F. I. Nwabue and J. N. Afiukwa, Environment and Pollution 1 (2), 183 (2012).

[25] A. Qishlaqi and F. Moore, American-Eurasian Journal of Agriculture and Environmental Sciences 2 (5), 565 (2007).

[26] S. J. Moja, J. S. Mnisi, M. M. Nindi and J. O. Okonkwo, Journal of Environmental Sciences and Health, Part A: Toxic/Hazardous substances and Environmental Engineering 48 (1), 99 (2013).

[27] HR (Home Remedies). Nickel benefits, deficiency symptoms and food sources. http://www.best-homeremedies.com/minerals/nickel.htm. Visited 15 January (2013).

[28] M. Kalay and M. Canli, Turk J Zool. 24, 429 (2000).

[29] Y. Von Schirnding, A. Mathee, P. Robertson and M. Kibel, $S$. A. Med. J. 91 (10), 870 (2001).

[30] M. J. Friedrich, JAMA 283 (23), 3057 (2000). 